\title{
Environmental mobility of trace elements present in dusts emitted from $\mathrm{Zn}-\mathrm{Pb}$ metallurgical processes
}

\author{
Zdzisław Adamczyk $^{1} \cdot$ Katarzyna Nowińska $^{1}$
}

Received: 8 September 2015 / Accepted: 20 May 2016/Published online: 2 June 2016

(c) The Author(s) 2016. This article is published with open access at Springerlink.com

\begin{abstract}
The paper presents results of investigations into possibility of migration to the soil and water environment of trace elements present in one of the main phases, zinc sulphide, emitted in dusts from various operations of pyrometallurgical extraction of $\mathrm{Zn}$ and $\mathrm{Pb}$ at the Miasteczko Śląskie Zinc Smelting Plant. The quantity of elements was estimated on the basis of: (1) dust fall, (2) zinc sulphide content in dust, (3) element content in zinc sulphide and (4) mobility of zinc sulphide under the hypergenic conditions of the soil and water environment of the Smelting Plant area. Among the elements considered, arsenic emitted with zinc sulphide contained in dusts from the Sintering Machine will pose a potential hazard for the soil and water environment of the Miasteczko Śląskie Zinc Smelting Plant area.
\end{abstract}

Keywords Lead · Zinc · Pyrometallurgy · Trace elements · Dust · Environment

\section{Introduction}

The Miasteczko Śląskie Zinc Smelting Plant is the only facility in Poland using the ISP (Imperial Smelting Process) pyrometallurgical process for simultaneous production of zinc and lead. The plant has been in operation since 1966. The production line at the Smelting Plant consists of Sintering Unit (Sintering Machine) with Sulphuric Acid

Katarzyna Nowińska

katarzyna.nowinska@polsl.pl

1 Institute of Applied Geology, Silesian University of Technology, Akademicka 2, 44-100 Gliwice, Poland
Plant, Shaft Furnace Unit, Lead Refining Plant and Zinc Rectification Unit (Zhao 2013).

During the production process dusts from various points of the production line are emitted into the environment. These dusts are much varied in terms of mineral composition (Lentz 2012; Nitta et al. 2008; Pattrick et al. 1993, Pattrick et al. 1998) which gives rise to diverse forms of metals present in the soils of the region. Soils in the area of Miasteczko Śląskie are mainly of sandy (podzolic) type with occasional occurrence of silty and boggy soils, alluvial soils and rendzinas. Most of the soils are classified as slightly acid or acid, which results in high mobility of metals in the soil and increased metal uptake by plants. The area of the Miasteczko Ślaskie Zinc Smelting Plant is highly contaminated with heavy metals, particularly with zinc $(84.7-630.9 \mathrm{mg} / \mathrm{kg}$ ) and lead $(853.7-9427.0 \mathrm{mg} / \mathrm{kg}$ ), and slightly less with cadmium (36.4-1036.5 mg/kg), copper $(32.2-500.0 \mathrm{mg} / \mathrm{kg})$ and arsenic $(83.0-768.0 \mathrm{mg} /$ $\mathrm{kg}$ ). Other heavy metals are present in concentrations lower than the limits defined for group $\mathrm{C}$ industrial areas. Zinc concentrations in underground water of the Zinc Smelting Plant area are relatively low, less than $10.00 \mathrm{mg} / \mathrm{L}$, occasionally exceeding $300.00 \mathrm{mg} / \mathrm{L}$. Maximum lead concentrations in underground water taken from monitoring wells located within the plant area reach ca. $1.00 \mathrm{mg} / \mathrm{L}$. Such low lead concentrations in water show that lead leaching is very slow. Noteworthy is the high content of arsenic in underground water at the plant site. It reaches $350.00 \mathrm{mg} / \mathrm{L}$ and indicates that this element is highly mobile (Smelting plant study-soil quality in the area 2010).

The area around the smelting plant consists mainly of farmland and forests. Scotch pine is the prevailing species with admixture of fir and birch. Elements present in dusts emitted by the Miasteczko Śląskie Smelting Plant are characterised by high bioavailability (Kicińska 2011). A 
small portion of them is bound in the crystalline lattice of minerals, and large portion is found in the exchange (mobile) positions. For this reason, the results of metal determinations in the wood of pines, birches and firs growing near the smelting plant have proved a statistical relationship between dust fall and metal accumulation in vegetation. This allows us to state that the vegetation growing in the vicinity of the smelting plant site limits the mobility of elements in the soil and water environment (Gerold-Śmietańska 2007).

Studies of the migration possibility of chemical elements contained in the dust emitted to the soil and water environment by the Miasteczko Ślaskie Zinc Smelting Plant form a basis for determining the mechanisms of pollutant transformations in that environment. The subject of investigations was dusts emitted to air from the stack of the Sintering Machine.

As it was proved, the main phase constituents of investigated dust emitted to the environment were (Adamczyk et al. 2010, 2013, 2015):

- sulphides- $\mathrm{ZnS}$ and $\mathrm{PbS}$,

- sulphate- $\mathrm{PbSO}_{4}$,

- oxides-zincite $(\mathrm{ZnO})$, wustite $(\mathrm{FeO})$ and minium $(\mathrm{PbO})$,

with substantial content of zinc sulphide.

The chemical composition of zinc sulphide from selected points of this process line was investigated (Adamczyk et al., 2010, 2015).

Mobility of zinc sulphide in the soil and water environment was assessed in relation to conditions prevailing in that environment ( $\mathrm{pH}, \mathrm{Eh}$, temperature). In an environment with a $\mathrm{pH}$ of 4.5-7.5 zinc sulphide may break down into ionic or solid forms. In the case of ionic forms, all accompanying elements present in zinc sulphide migrate along with the main ions (of zinc and sulphur) to ground water.

The aim of the study outlined in this paper was to determine the possibility of migration of trace elements from zinc sulphide emitted by the Sintering Machine (as the main emission source of arsenic and tin) to ground waters.

\section{Methodology}

Investigations were conducted by the authors in the years 2005-2010. Dust samples from the current production of the smelting plant were taken in 12 series (120 samples in total). Chemical and mineral composition of the samples was determined.

Chemical composition was determined by means of X-ray fluorescence (XRF) using a Rigaku ZSX Primus wavelength-dispersive X-ray fluorescence spectrometer.
The spectrometer was fitted with a rhodium X-ray tube with variable voltage adjustment between 20 and $60 \mathrm{kV}$, and $\mathrm{LiF}, \mathrm{Ge}$ and several synthetic analysing crystals.

Mineral constituents were identified using polarised light optical microscopy and chemical composition determined in micro-areas. A Zeiss Axioplan microscope was used. Chemical composition was determined in micro-areas using a JEOL X-ray micro-analyser (EPMA) with wavelength- and energy-dispersive spectrometers (WDS, EDS) and with an electron backscatter diffraction accessory from Oxford Instruments. Ten measurements were made for each grain, and average was taken as the final result.

The estimation of the load of trace elements introduced into ground waters as a consequence of zinc sulphide decomposition was made for the scenario least favourable to the environment: all of the zinc sulphide from dust fallout from the Sintering Machine into the soil and water environment is decomposed.

To ensure correctness of these estimates, additional considerations must be taken into account. Dust emissions from the Zinc Smelting Plant amount to $48 \mathrm{Mg} / \mathrm{year}$, of which the emissions from the Smelting Machine constitute more than $7 \%$. The adopted value of annual dust fall was based on a detailed analysis of dust fall measurements in 25 points around the Smelting Plant. This analysis indicates that the average dust fall is $59 \mathrm{~g} /\left(\mathrm{m}^{2} \times\right.$ year) (median equal to $58 \mathrm{~g} /\left(\mathrm{m}^{2} \times\right.$ year) (Adamczyk et al. 2010).

In order to determine the mobility of the elements present in zinc sulphide, geochemical modelling based on Eh$\mathrm{pH}$ diagrams was applied. These diagrams were plotted for conditions characteristic of the soil and water environment in the Smelting Plant area.

For this reason the following values were adopted: mean precipitation $700 \mathrm{~mm} / \mathrm{year}$, mean temperature in winter season $-5^{\circ} \mathrm{C}$, maximum temperature in summer season $+30{ }^{\circ} \mathrm{C}$. Studies were performed within the water stability region, within Eh range of $-0.8 \ldots+1.4 \mathrm{~V}$ and $\mathrm{pH}$ range of $0 \ldots 14$ ( $\mathrm{pH}$ of the soil and water environment under study is within the range $4.5 \ldots 7.5)$. The diagrams show the stability regions of the forms of occurrence of trace elements contained in zinc sulphide at extreme seasonal temperatures, i.e. $-5^{\circ} \mathrm{C}$ and $+30{ }^{\circ} \mathrm{C}$.

\section{Results}

Based on the data on the mean chemical composition of the dust from the Sintering Machine (Table 1) and results of dust phase composition determination made by the authors (Adamczyk et al. 2010, 2015), the fractions of zinc sulphide and other phase components (lead sulphide, lead sulphate, zinc oxide, iron oxide and lead oxide) were calculated (Table 1). 
Table 1 Chemical and phase composition of dust from the Sintering Machine (dust emitted to the air)

\begin{tabular}{lcll}
\hline Element & Content $(\mathrm{wt} \%)$ & Phase & Content (wt\%) \\
\hline $\mathrm{Si}$ & 0.69 & $\mathrm{PbS}$ & 14.9 \\
$\mathrm{Al}$ & 0.14 & $\mathrm{ZnS}$ & 25.6 \\
$\mathrm{Fe}$ & 5.40 & $\mathrm{PbSO}_{4}$ & 22.4 \\
$\mathrm{Mn}$ & 0.12 & $\mathrm{ZnO}$ & 4.3 \\
$\mathrm{Mg}$ & 0.15 & $\mathrm{FeO}$ & 5.4 \\
$\mathrm{Ca}$ & 1.55 & $\mathrm{PbO}$ & 18.0 \\
$\mathrm{~K}$ & 0.46 & $\mathrm{Total}$ & 90.6 \\
$\mathrm{~Pb}$ & 50.32 & & \\
$\mathrm{Zn}$ & 21.24 & & \\
$\mathrm{~S}$ & 13.61 & & \\
$\mathrm{Ag}$ & 1.08 & & \\
$\mathrm{As}$ & 0.55 & & \\
$\mathrm{Cd}$ & 3.89 & & \\
$\mathrm{Cu}$ & 0.18 & & \\
$\mathrm{Se}$ & 0.22 & \\
$\mathrm{Sb}$ & 0.16 & \\
$\mathrm{Sn}$ & 0.24 & \\
$\mathrm{Total}$ & 100.0000 & \\
\hline $\mathrm{Average}$ & & & \\
\hline
\end{tabular}

Average of 12 measurements. Analytical error $0.01 \%$
Calculations were made based on data related to: (1) content of the elements determined in defined points of the micro-area, (2) stoichiometric ratios, taking into account atomic masses of the elements contained in the identified phase constituent.

The list above indicates that the abundant phase in the dust studied is zinc sulphide $(25.6 \mathrm{wt} \%)$. A significant constituent of the dust is also lead sulphate-second most voluminous phase $(22.4 \mathrm{wt} \%)$. Percentage of all phases amounts to $90.4 \mathrm{wt} \%$, and the remaining elements, i.e. $\mathrm{Si}$, $\mathrm{Al}, \mathrm{Mn}, \mathrm{Mg}, \mathrm{Ca}, \mathrm{K}, \mathrm{Ag}, \mathrm{As}, \mathrm{Cd}, \mathrm{Cu}, \mathrm{Se}, \mathrm{Sb}$ and $\mathrm{Sn}$, are presumably substituents of the main elements in these phases, and percentage thereof is $9.6 \mathrm{wt} \%$.

Zinc sulphide will decompose in the water and soil environment, and trace elements will be released along with it. In the average chemical composition of zinc sulphide coming from the Sintering Machine, $\mathrm{Fe}$ and $\mathrm{Pb}$ occur in concentrations exceeding $1 \mathrm{wt} \%$; and also $\mathrm{Cd}$ is present in the amount of approximately $1 \mathrm{wt} \%$. These elements most probably constitute separate phases in the form of inclusions in zinc sulphide. Concentrations of other elements, i.e. As, $\mathrm{Se}, \mathrm{Mn}, \mathrm{Sn}, \mathrm{Sb}, \mathrm{Cu}, \mathrm{Ag}, \mathrm{Ca}$, are below $0.4 \mathrm{wt} \%$ (Table 2). These elements may form admixtures

Table 2 Chemical composition of zinc sulphide in dust from the Sintering Machine: dusts PR1 and PR2 (in wt\%)

\begin{tabular}{|c|c|c|c|c|c|c|}
\hline \multirow[t]{2}{*}{ Element } & \multicolumn{3}{|c|}{ Measurement point } & \multirow{2}{*}{$\begin{array}{l}\text { Average PR2 } \\
\text { (Nowinska and } \\
\text { Adamczyk 2015) }\end{array}$} & \multirow{2}{*}{$\begin{array}{l}\text { Average PR3 } \\
\text { (Adamczyk et al. 2010) }\end{array}$} & \multirow{2}{*}{$\begin{array}{l}\text { Average chemical composition } \\
\text { of sphalerite PR2 and PR3 }\end{array}$} \\
\hline & PR2-6 & PR2-7 & PR2-8 & & & \\
\hline $\mathrm{S}$ & 32.33 & 31.87 & 35.63 & 33.43 & 33.05 & 33.28 \\
\hline $\mathrm{Ca}$ & 0.00 & 0.05 & 0.00 & 0.02 & 0.03 & 0.02 \\
\hline $\mathrm{Mn}$ & 0.10 & 1.31 & 0.00 & 0.18 & 0.25 & 0.21 \\
\hline $\mathrm{Fe}$ & 0.61 & 1.68 & 6.79 & 2.87 & 4.41 & 3.50 \\
\hline $\mathrm{Cu}$ & 0.01 & 0.25 & 0.00 & 0.12 & 0.09 & 0.11 \\
\hline $\mathrm{Zn}$ & 64.50 & 60.33 & 56.76 & 61.23 & 57.79 & 59.81 \\
\hline As & 0.50 & 0.79 & 0.43 & 0.34 & 0.25 & 0.31 \\
\hline $\mathrm{Se}$ & 0.00 & 0.00 & 0.00 & 0.07 & 0.47 & 0.24 \\
\hline $\mathrm{Ag}$ & 0.00 & 0.00 & 0.00 & 0.06 & 0.11 & 0.08 \\
\hline $\mathrm{Cd}$ & 1.95 & 1.02 & 0.11 & 0.71 & 1.23 & 0.92 \\
\hline Sn & 0.00 & 0.12 & 0.28 & 0.10 & 0.36 & 0.20 \\
\hline $\mathrm{Sb}$ & 0.00 & 0.26 & 0.00 & 0.09 & 0.32 & 0.19 \\
\hline $\mathrm{Pb}$ & 0.00 & 2.32 & 0.00 & 0.78 & 1.64 & 1.13 \\
\hline Total & 100.00 & 100.00 & 100.00 & Average of 10 tests & Average of 7 tests & Average of 17 tests \\
\hline \multicolumn{7}{|c|}{ Phase percentage } \\
\hline $\mathrm{PbS}$ & 0.00 & 2.76 & 0.00 & 0.91 & 1.92 & 1.33 \\
\hline $\mathrm{ZnS}$ & 96.59 & 92.41 & 85.20 & 92.11 & 87.70 & 90.30 \\
\hline FeS-FeS2 & 1.32 & 3.71 & 14.68 & 6.21 & 8.54 & 7.17 \\
\hline $\mathrm{CdS}$ & 2.09 & 1.12 & 0.12 & 0.76 & 1.33 & 1.00 \\
\hline Total & 100.00 & 100.00 & 100.00 & & & \\
\hline
\end{tabular}

Analytical error $0.01 \%$ 
both in zinc sulphide and in the phases that constitute inclusions therein.

Therefore, when considering the possibility of migration of these elements into the environment after the decomposition of zinc sulphide, content of these elements in inclusions, i.e. in $\mathrm{PbS}, \mathrm{FeS}-\mathrm{FeS}_{2}, \mathrm{CdS}$, should be indicated. In order to determine the migration of elements into the environment, only two of them were considered, namely As and Sn. Discussion of all potential migrating elements would require a much broader study. Furthermore, these two elements may be hazardous to the environment due to their toxicity.

As stated in previous publications of the authors (Adamczyk et al. 2010), the average content of As and Sn is as follows:

- in $\mathrm{PbS}-0.0977 \mathrm{wt} \%$ As and $0.0622 \mathrm{wt} \% \mathrm{Sn}$,

- in $\mathrm{FeS}-\mathrm{FeS}_{2}-0.3598 \mathrm{wt} \%$ As and $0.0442 \mathrm{wt} \% \mathrm{Sn}$,

and taking the average content of these phases in zinc sulphide $\left(\mathrm{PbS}-1.326 \mathrm{wt} \%, \mathrm{FeS}-\mathrm{FeS}_{2}-7.173 \mathrm{wt} \%\right)$, the weighted average for these phases is as follows:

- As-0.0013 wt\% in $\mathrm{PbS}$ and $0.0258 \mathrm{wt} \%$ in $\mathrm{FeS}-\mathrm{FeS}_{2}$, and

- $\mathrm{Sn}-0.0008 \mathrm{wt} \%$ in $\mathrm{PbS}$ and $0.0131 \mathrm{wt} \%$ in $\mathrm{FeS}-\mathrm{FeS}_{2}$.

Thus, the average content of As in zinc sulphide is $0.2778 \mathrm{wt} \%$ and that of $\mathrm{Sn}$ is $0.1846 \mathrm{wt} \%$.

Dust emission from the Sintering Machine, when considering annual emissions from the Plant, is $3.36 \mathrm{Mg}$, whereas the dust fall from that emission point is $4.13 \mathrm{~g} /$ $\left(\mathrm{m}^{2} \times\right.$ year $)$. Fraction of zinc sulphide in the dust is calculated at $25.6 \mathrm{wt} \%$; therefore, the amount of this phase emitted annually from the stack of the Sintering Machine is $0.8602 \mathrm{Mg}$, which translates into $1.0573 \mathrm{~g} /$ $\left(\mathrm{m}^{2} \times\right.$ year) in fallen dust (Table 3$)$. Along with zinc sulphide, trace elements are discharged into the environment, among them As and $\mathrm{Sn}$, in amounts of $0.0093 \mathrm{Mg} /$ year and $0.0062 \mathrm{Mg} /$ year, respectively, and $0.0115 \mathrm{~g} /\left(\mathrm{m}^{2} \times\right.$ year $)$ As and $0.0076 \mathrm{~g} /\left(\mathrm{m}^{2} \times\right.$ year $) \mathrm{Sn}$ in fallen dust.

The worst case scenario may be that (it may be assumed that in the least favourable conditions) all of the zinc sulphide in fallen dust $\left(1.0573 \mathrm{~g} /\left(\mathrm{m}^{2} \times\right.\right.$ year $\left.)\right)$ will be decomposed in the soil and water environment. In such a case all trace elements bound into that phase will migrate into that environment. Under such assumptions, the maximum concentration of zinc in ground water may reach $9.52 \mathrm{mg} \mathrm{Zn} / \mathrm{L}$ (with annual precipitation of $700 \mathrm{~mm}$ ). Concentrations of arsenic and tin in ground water will, under these conditions, reach $0.16 \mathrm{mg}$ As/L and $0.11 \mathrm{mg}$ $\mathrm{Sn} / \mathrm{L}$, respectively.

According to the latest studies (Nowinska and Adamczyk 2015), zinc sulphide will decompose in the soil and water environment within the entire range of $\mathrm{pH}$ values, forming, among others, $\mathrm{Zn}^{2+}$ and $\mathrm{Zn}(\mathrm{OH})^{+}$ ions, which are mobile in the environment. As and $\mathrm{Sn}$ released during such decomposition create the following forms:

- As-ionic: $\mathrm{HAsO}^{3-}, \mathrm{AsO}_{4}{ }^{3-}, \mathrm{HAsO}_{4}{ }^{2-}, \mathrm{H}_{2} \mathrm{AsO}_{4}{ }^{-}$, solid: As,

- Sn-ionic: $\mathrm{Sn}(\mathrm{OH})_{6}^{2-}$, solid: $\mathrm{SnO}_{2}$ and $\mathrm{Sn}\left(\mathrm{SO}_{4}\right) \mathrm{O}_{2}$,

irrespective of seasonal temperature changes $\left(-5 \ldots+30^{\circ} \mathrm{C}\right)$. Within the $\mathrm{pH}$ range characteristic of the soil and water environment in the area covered by the study, $\mathrm{pH}=4.5 \ldots 7.5$, only the following ions will be present: $\mathrm{HAsO}^{3-}, \mathrm{HAsO}_{4}{ }^{2-}, \mathrm{H}_{2} \mathrm{AsO}_{4}{ }^{-}$. Therefore, only ions of arsenic will be mobile in the environment, with no tin ions present. Tin in the $\mathrm{pH}$ range of 4.5 to 7.5 forms stable $\mathrm{SnO}_{2}$ (Fig. 1).
Table 3 Content of Zn, As, and $\mathrm{Sn}$ in dust emissions and fallen dust from the stack of the Sintering Machine (E3) with zinc sulphide amount taken into account

\begin{tabular}{lll}
\hline Emission $(\mathrm{Mg} /$ year $)$ & Amount of $\mathrm{ZnS}$ in dust emissions from E3 & 0.8602 \\
& Zn fraction in emissions from E3 & 0.5419 \\
& Fraction of As contained in $\mathrm{ZnS}$ in emissions from E3 & 0.0093 \\
& Fraction of $\mathrm{Sn}$ contained in $\mathrm{ZnS}$ in emissions from E3 & 0.0062 \\
Dust fall $\left(\mathrm{g} /\left(\mathrm{m}^{2} \times\right.\right.$ year $\left.)\right)$ & Amount of $\mathrm{ZnS}$ in fallen dust from E3 & 1.0573 \\
& Fraction of $\mathrm{Zn}$ in fallen dust from E3 & 0.6661 \\
& Fraction of As contained in ZnS in fallen dust from E3 & 0.0115 \\
& Fraction of Sn contained in $\mathrm{ZnS}$ in fallen dust from E3 & 0.0076 \\
\hline
\end{tabular}



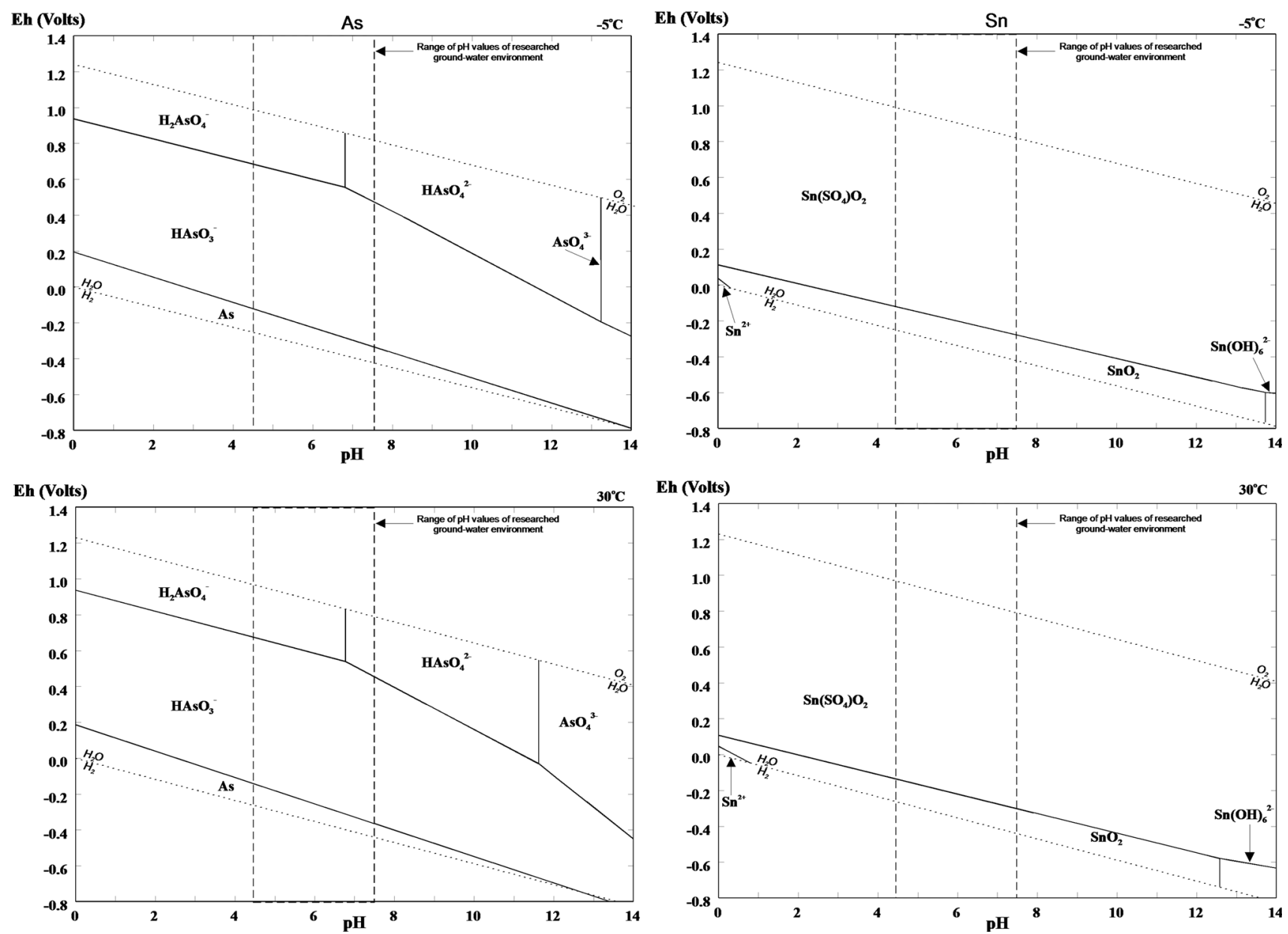

Fig. 1 Mobility of As and Sn from zinc sulphide emitted by the Sintering Machine (emission point E3) to the soil and water environment at -5 and $30^{\circ} \mathrm{C}$

\section{Conclusions}

Zinc sulphide is one of the main forms present in the dust discharged from the stack of the Miasteczko Śląskie Zinc Smelting Plant. Along with zinc sulphide, trace elements are discharged into the environment, among them As and $\mathrm{Sn}$, in amounts of $0.0093 \mathrm{Mg} / \mathrm{year}$ and $0.0062 \mathrm{Mg} /$ year, respectively, and $0.0115 \mathrm{~g} /\left(\mathrm{m}^{2} \times\right.$ year $)$ As and $0.0076 \mathrm{~g} /$ $\left(\mathrm{m}^{2} \times\right.$ year $) \mathrm{Sn}$ in fallen dust.

Zinc sulphide will decompose into mobile forms $\mathrm{Zn}^{2+}$ and $\mathrm{Zn}(\mathrm{OH})^{+}$in the soil and water environment over the whole $\mathrm{pH}$ range, and thereby trace elements As and $\mathrm{Sn}$ contained in zinc sulphide will be released to the environment. Movement of metals into other environmental compartments, i.e. ground water, surface water, or the atmosphere, is expected to be minimal as long as the retention capacity of the soil is not exceeded. The extent of movement of metal in the soil system is closely related to the solution and surface chemistry of the soil and to the specific properties of metal and associated waste matrix.
Changes in the soil environment over time, such as the degradation of the organic waste matrix, changes in $\mathrm{pH}$, redox potential, or soil solution composition, due to various remediation schemes or to natural weathering processes may also enhance metal mobility (ground water issue). Biogeochemical redox processes strongly influence also mobility of metalloids such as arsenic (As) and antimony $(\mathrm{Sb})$. Environmental As chemistry has received great attention during the last two decades due to the worldwide health impacts of As-contaminated water and soils. Arsenic in natural waters and soils is closely related to the presence of iron (hydr)oxides being arsenate and arsenite strongly sorbed onto the surfaces of Fe oxides, forming inner-sphere complexes. The simultaneous presence of high dissolved As and Fe(II) concentrations in anoxic groundwater has led to the conclusion that reductive dissolution of As rich $\mathrm{Fe}$ (III) (hydr)oxides mobilises geogenic As (Borch et al. 2010, Voliante et al. 2010)

The plotted Eh and $\mathrm{pH}$ diagrams indicate that within the $\mathrm{pH}$ range of 4.5-7.5, which is characteristic of the soil and 
water environment of the area under study, the mobile forms of arsenic in this environment include $\mathrm{HAsO}^{3-}$, $\mathrm{HAsO}_{4}{ }^{2-}, \mathrm{H}_{2} \mathrm{AsO}_{4}{ }^{-}$. Under these conditions tin occurs in the stable form of $\mathrm{SnO}_{2}$.

It may therefore be assumed that among the elements considered, arsenic emitted with zinc sulphide contained in dusts from the Sintering Machine will create a potential hazard for the soil and water environment of the Miasteczko Śląskie Zinc Smelting Plant area.

Open Access This article is distributed under the terms of the Creative Commons Attribution 4.0 International License (http://crea tivecommons.org/licenses/by/4.0/), which permits unrestricted use, distribution, and reproduction in any medium, provided you give appropriate credit to the original author(s) and the source, provide a link to the Creative Commons license, and indicate if changes were made.

\section{References}

Adamczyk Z, Melaniuk-Wolny E, Nowińska K (2010) The mineralogical and chemical study of feedstock mixtures and byproducts from pyrometallurgical process of zinc and lead production. Wydawnictwo Politechniki Śląskiej, Gliwice

Adamczyk Z, Nowińska K, Melaniuk-Wolny E (2013) Variation of the content of accompanying elements in galena in pyrometallurgical process of zinc and lead production. Acta Montan Slovaca 18(3):158-163

Adamczyk Z, Nowińska K, Melaniuk-Wolny E (2015) Accompanying elements in sphalerite in pyrometallurgical process of zinc and lead production. Mater Manuf Process 30(12):1457-1464
Borch T, Kretzschmar R, Kappler A, Van Cappelen P, Ginder-Vogel M, Voegelin A, Campbell K (2010) Biogeochemical redox processes and their impact on contaminant dynamics. Environ Sci Technol 44:15-23

Gerold-Śmietańska I (2007) Kierunki przemian fitocenoz borowych obserwowanych na stałych powierzchniach badawczych w okolicach Huty Cynku w Miasteczku Śląskim. Dissertation, University of Silesia

Kicińska A (2011) Occurrence and mobility of zinc, lead and cadmium in soils polluted by mining and metallurgical industries. Ochrona Środowiska z Zasobów Naturalnych 49:152-162

Lentz DR (2012) Sphalerite and arsenopyrite at the Brunswick no. 12 massive-sulfide deposit, Bathurst Camp, New Brunswick: Constraints on p-t evolution. Can Mineral 40:19-31

Nitta E, Kimata M, Hoshino M, Echigo T, Hamasaki A, Nishida N, Shimizu M, Akasaka T (2008) Crystal chemistry of ZnS minerals formed as high-temperature volcanic sublimates: matraite identical with sphalerite. J Mineral Petrol Sci 103:145-151

Nowińska K, Adamczyk Z (2015) Mobility in ground-water environment of $\mathrm{ZnS}$ contained in pyrometallurgical $\mathrm{Zn}-\mathrm{Pb}$ dust, vol 1. Clausthal-Zellerfeld, GDMB, pp 31-39

Pattrick RAD, Dorling M, Polya DA (1993) TEM study of indium and copper-bearing growth-banded sphalerite. Can Mineral 31:105-117

Pattrick RAD, Mosselmans JFW, Charnock JM (1998) An X-ray absorption study of doped sphalerites. Eur J Mineral 10:239-249

Smelting plant study-soil quality in the area. Technical documentation. 2010

Voliante A, Cozzolino V, Perelomov L, Caporale AG, Pigna M (2010) Mobility and bioavailability of heavy metals and metalloids in soil environments. J Soil Sci Plant Nutr 10(3):268-292

Zhao B (2013) Lead and zinc sintering. In: Sintering applications. InTech, Rijeka, pp 165-199 